\title{
Verrucous leukoplakia of the red border caused by the use of IQOS heated tobacco product (a case report)
}

\author{
H. I. Makurina $\mathbb{D}^{\star A-F}$, O. I. Makarchuk ${ }^{\mathrm{E}}$, I. P. Dmytrenko ${ }^{\mathrm{C}}$, A. V. Holovkin $\mathbb{1}^{\mathrm{B}}$, \\ I. A. Sokolovska®G A. S. Chornenka ${ }^{D}$
}

Zaporizhzhia State Medical University, Ukraine

A - research concept and design; $\mathrm{B}$ - collection and/or assembly of data; C - data analysis and interpretation; D - writing the article; $\mathrm{E}$ - critical revision of the article; $\mathrm{F}$ - final approval of the article

Aim. To analyze possibility of development and describe the clinical case of the red border verrucous leukoplakia caused by the use of IQOS heated tobacco product and HEETS sticks and propose personalized clinical, diagnostic and therapeutic algorithm of a patient management.

Materials and methods. Based on own observation, this article describes a clinical case of verrucous leukoplakia of the red border arising in a patient who used IQOS heated tobacco product and HEETS sticks. Clinical, laboratory, instrumental examination and treatment were performed on the basis of the Department of Dermatovenereology and Cosmetology with the course of Dermatovenereology and Aesthetic Medicine of the Postgraduate Education Faculty of Zaporizhzhia State Medical University.

Results. The plaque-type verrucous leukoplakia of the red border was diagnosed based on clinical examination of the patient and diagnosis verification by means of laboratory examination and dermatoscopy. Considering the possible traumatic lesion, a high probability of the disease recurrence, patient's refusal of surgical treatment methods, the topical therapy for affected area with the use of combined drug containing glucocorticosteroid, antibacterial and antimycotic components was prescribed for 1 month followed by long-term therapy using $1 \%$ pimecrolimus cream.

Conclusions. Based on the literature analysis, it was found out that IQOS heated tobacco product and HEETS sticks can promote the development of such manifestations of oxidative stress and endothelial dysfunction as inflammation, infection, fibrosis, oncologic pathology and become one of initiating agents for the occurrence of red border verrucous leukoplakia. The use of topical glucocorticosteroids combined with topical inhibitors of calcineurin can be proposed as an alternative to surgical methods of treatment for leukoplakia and it requires more detailed study.

\section{Верукозна лейкоплакія червоної облямівки губ на тлі використання системи нагрівання тютюну IQOS (киінічний випадок)}

\section{Г. І. Макуріна, О. І. Макарчук, І. П. Амитренко, А. С. Головкін, І. А. Соколовська, А. С. Чорненька}

Мета роботи -проаналізувати можливість розвитку та описати клінічний випадок верукозної лейкоплакії червоної облямівки губ на тлі використання системи нагрівання тютюну IQOS і стіків HEETS; запропонувати персоніфікований клініко-діагностичний і терапевтичний алгоритм ведення пацієнта.

Матеріали та методи. Описали власне спостереження клінічного випадку хворої на верукозну лейкоплакію червоної облямівки нижньої губи, що розвинулася на тлі куріння з використанням системи нагрівання тютюну IQOS і стіків HEETS. Клінічне, лабораторне, інструментальне обстеження та лікування виконали на базі кафедри дерматовенерології та косметології з курсом дерматовенерології і естетичної медицини фракультету післядипломної освіти Запорізького державного медичного університету.

Результати. На підставі клінічного обстеження пацієнта та верифбікації діагнозу за допомогою лабораторного дослідження, дерматоскопії встановили діагноз верукозної лейкоплакії червоної облямівки нижньої губи, бляшкового типу. Враховуючи можливу травматизацію, високу ймовірність рецидиву захворювання, відмову пацієнтки від хірургічних методів лікування, призначили топічну терапію вогнища ураження з використанням комбінованого препарату, який містить глюкокортикостероїдний, антибактеріальний та антимікотичний компоненти, протягом 1 місяця з наступною тривалою терапією 1 \% кремом пімекролімусу.

Висновки. За даними фахової літератури, система нагрівання тютюну IQOS і стіки HEETS можуть спричиняти розвиток таких проявів окисного стресу й ендотеліальної дисфрункції, як запалення, інфекція, фіброз, онкологічна патологія, а також стати одним із факторів виникнення лейкоплакії червоної облямівки губ. Застосування топічних глюкокортикостероїдів у поєднанні з топічними інгібіторами кальціневрину може бути альтернативою хірургічним методам терапії лейкоплакії.
Key words: verrucous leukoplakia, precancerous conditions, IQOS HEETS.

Zaporozhye medical journal 2020; $22(6), 885-890$

*E-mail: makurinagalina1@ gmail.com

Ключові слова: верукозна мейкоплакія, перелракові захворювання IQOS, HEETS.

Запорізький медичний журнал 2020. T. 22, № 6(123) C. $885-890$

\section{Веррукозная лейкоплакия красной каймы губ на фоне использования системы нагрева табака IQOS (клинический случай)}

\section{Г. И. Макурина, А. И. Макарчук, И. П. Амитренко, А. В. Головкин, И. А. Соколовская, А. С. Чёрненькая}

Цель работы -проанализировать возможность развития и описать клинический случай веррукозной лейкоплакии красной каймы губ на фоне использования системы нагревания табака IQOS и стиков HEETS; предложить персонифицированный клинико-диагностический и терапевтический алгоритм ведения пациента. 
Киючевые слова: веррукозная мейкоплакия, предраковые заболевания, IQOS, HEETS.

Запорожский медицинский журнал. 2020. T. 22, № 6(123). C. $885-890$

Материалы и методы. Описано собственное наблюдение клинического случая больной веррукозной лейкоплакией красной каймы нижней губы, которая развилась на фоне курения с использованием системы нагрева табака IQOS и стиков HEETS. Клиническое, лабораторное, инструментальное обследование и лечение проведены на базе кафедры дерматовенерологии и косметологии с курсом дерматовенерологии и эстетической медицины факультета последипломного образования Запорожского государственного медицинского университета.

Результаты. На основе клинического обследования пациента и верисрикации диагноза с помощью лабораторного обследования, дерматоскопии установлен диагноз веррукозной лейкоплакии красной каймы нижней губы, бляшечного типа. Учитывая возможную травматизацию, высокую вероятность рецидива заболевания, отказ пациентки от хирургических методов лечения, назначена топическая терапия очага поражения с использованием комбинированного препарата, содержащего глюкокортикостероидный, антибактериальный и антимикотический компоненты, в течение 1 месяца с последующей длительной терапией 1 \% кремом пимекролимуса.

Выводы. По данным специализированной литературы, система нагрева табака IQOS и стики HEETS могут способствовать развитию таких проявлений окислительного стресса и эндотелиальной дисфуннции, как воспаление, инфекция, фиброз, онкологическая патология, а также стать одним из факторов возникновения лейкоплакии красной каймы губ. Применение топических глюкокортикостероидов в сочетании с топическими ингибиторами кальциневрина может быть альтернативой хирургическим методам терапии лейкоплакии.

In recent years, Heat-Not-Burn tobacco products are actively used as an alternative to traditional tobacco smoking. IQOS (I Quit Ordinary Smoking) - is a new heating system of purified tobacco. It was developed by Phillip Morris International (PMI) in 2014. As declared by the manufacturer (PMI), IQOS heats specially prepared tobacco mixture below $350{ }^{\circ} \mathrm{C}$ such that an aerosol is produced instead of burning it with no fire and less smoke. This heated tobacco product works with three main components: tobacco stick (called HEETS or a HeatStick), IQOS holder and a charger. A user inserts the tobacco stick into the holder and the tobacco is heated with an electronic heating blade $[1,2]$.

Using IQOS tobacco heating system (THS) gives no fire and less smoke as declared by the manufacturer, eliminating the undesirable effects of traditional tobacco products by reducing the levels of toxic chemicals. However, the heating temperature is sufficient for occurrence of pyrolitic reactions in aerosol, which is produced during the product use. Toxic substances (thermal decomposition products of propylene glycol, glycerin etc.), namely formaldehyde, acrolein, phenol, acetaldehyde, diacetyl, acetol (propionic aldehyde), furfurol etc. are included in the aerosol. Concentration of these substances correlates with an increase in the product heating temperature (a study was conducted at the temperature of $180^{\circ} \mathrm{C}, 200^{\circ} \mathrm{C}, 220^{\circ} \mathrm{C}$ ) [3].

Using HEETS and IQOS, the mainstream aerosol contains higher concentrations of propylene glycol (240-850 $\mu \mathrm{g} / \mathrm{stick})$, acetol (140-260 $\mu \mathrm{g} / \mathrm{stick})$, glycerin (360 $\mu \mathrm{g} / \mathrm{stick})$ and acetaldehyde $(210 \mu \mathrm{g} / \mathrm{stick})$ as compared to traditional cigarettes: $11-28 \mu \mathrm{g} /$ cigarette, $50-110 \mu \mathrm{g} /$ cigarette, $18 \mu \mathrm{g} /$ cigarette and $25-45 \mu \mathrm{g} /$ cigarette, respectively. However, nicotine level generated by THS is different, and ranges from $1200 \mu \mathrm{g} / \mathrm{stick}$ to $1400 \mu \mathrm{g} / \mathrm{stick}$, and it is 1900 $\mu \mathrm{g} /$ cigarette in a traditional cigarette [4].

Besides, after the use of purified tobacco, carbonization is occurred through pyrolysis. Following the recommendations and instructions of the manufacturer as to the product, charring of the tobacco plug as well as melting of the polymer-film filter are increased. Release of formaldehyde, cyanhydrin compounds (for example acetocyanhydrin) was observed at $90{ }^{\circ} \mathrm{C}$, which is substantially lower than the maximum temperature reached in usual products usage, and that is the problem because these substances are toxic in small concentrations [5].
Information as to IQOS influence on health is rather limited. However, Noel J. Leigh et al. found out that metabolic activity and vitality of $\mathrm{H} 292$ bronchus epithelium cells were decreased during IQOS use in the same way as with the use of traditional cigarettes (in comparison with air control) [6]. Moreover, Sukhwinder Singh Sohal et al. have shown that the use of IQOS as well as traditional cigarettes is toxic for human bronchial epithelial cells (Beas-2B) and smooth muscle cells of respiratory tract. IQOS exposure induces release of interleukin-8, which is one of the main pro-inflammatory chemokines. There was a presence of mitochondrial dysfunction, which induces or worsens inflammatory process in lung tissue. IQOS provokes type 1collagen and fibronectin induction by above-mentioned cells, enabling epithelial-mesenchymal transition that in its turn causes remodeling of lung tissue and pulmonary fibrosis. Considering this information, IQOS has potential for occurrence and increase in manifestations of oxidative stress and inflammation, infections, COPD, asthma as well as provocation of lung tissue fibrosis and cancer [7].

By studying on rats, Pooneh Nabavizadeh, Jiangtao Liu et al. revealed that in case of traditional cigarettes use as well as IQOS, the endothelial function of vessels is disturbed, that is the risk factor for cardio-vascular diseases occurrence, which are at the first place in mortality rate among adults in the world according to the World Health Organization data. Levels of nicotine and cotinine in the blood serum were considerably higher in rats exposed to IQOS in comparison with the traditional cigarette-exposed group [8].

In the same way as traditional cigarettes, IQOS heated tobacco products release significant levels of carcinogenic tobacco-specific nitrosamines (TSNA) such as nitrosamine-ketone, N-nitrosonornicotine, $\mathrm{N}$-nitrosoanatabine and $\mathrm{N}$-nitrosoanabasine. Although IQOS tobacco heated products release less concentrations of TSNA than traditional cigarettes, their quantity is considerably higher in comparison to the electronic cigarettes [9]. Above-mentioned nitrosamines are the most carcinogenic of the known tobacco-specific nitrosamines. Substantial evidence underlines the role of TSNA as the important causative factors for cancer of the lung, pancreas, esophagus, and oral cavity in individuals who use tobacco products [10].

Samuel James Brake et al. concluded that smoking (both traditional cigarettes and IQOS or electronic cigarettes) activates angiotensin-converting enzyme-2 (ACE2) 
receptor. The ACE2 receptor enables a human S protein cell-binding site for SARS-coronavirus (SARS-CoV) that contributes to easier person-to-person spread of the virus, prolonged persistence in an organism, protection against immunological surveillance mechanisms, thus making smokers vulnerable to Covid-19 and increasing an incidence of complicated course and mortality rate regardless of chosen smoking product [11].

Taking into account the multi-component chemical content of sticks and presence of toxic chemical substances in aerosol, a certain probability of skin pathology occurrence can be assumed due to IQOS heated tobacco products contact. Absence of observations described in the literature regarding this trend prompted us to focus attention on this problem and present a clinical case of verrucous leukoplakia of the red border (lower lip) development in an IQOS smoker.

\section{Aim}

To analyze possibility of development and describe the clinical case of the red border verrucous leukoplakia caused by the use of IQOS heated tobacco product and HEETS sticks and propose personalized clinical, diagnostic and therapeutic algorithm of a patient management.

\section{Materials and methods}

Based on own observation, this article describes the clinical case of verrucous leukoplakia of the red border arising in a patient who used IQOS heated tobacco product and HEETS sticks. Examination and treatment were performed on the basis of the Department of Dermatovenereology and Cosmetology with the course of Dermatovenereology and Aesthetic Medicine of Postgraduate Education Faculty of Zaporizhzhia State Medical University and Municipal Institution "Zaporizhzhia Regional Dermatovenereological Clinical Dispensary" of Zaporizhzhia Municipal Council. Clinical, laboratory (general, biochemical) methods of examination and dermatoscopy were used to diagnose and follow-up.

\section{Case report}

The patient L, born in 1956, visited dermatovenereologist of Zaporizhzhia Regional Dermatovenereological Clinical Dispensary with the complaint of lesion area appearance on the lower lip accompanied by burning pain and insignificant itching. Past medical history revealed no relevant findings. On personal history, the patient reported of smoking since last 26 years and not being able to quit smoking. She had bronchial asthma attacks due to traditional tobacco smoking. On the advice of a doctor, she started to use HEETS sticks (Turquoise, Yellow, Amber) and IQOS heated tobacco product in order to change the traditional method of tobacco smoking since 01.12.2018, that caused stabilization of respiratory system condition, but in her opinion, it became the trigger for changes of the red border skin. After 4-5 months of every day use of IQOS, the affected area appeared on the lower lip. The lesion area increased in size gradually and started to disturb her.

In early May 2019, at the distance of approximately $1.0-1.5 \mathrm{~cm}$ from the left corner of the mouth on the lower lip in the zone of usual cigarette placing, a rash appeared

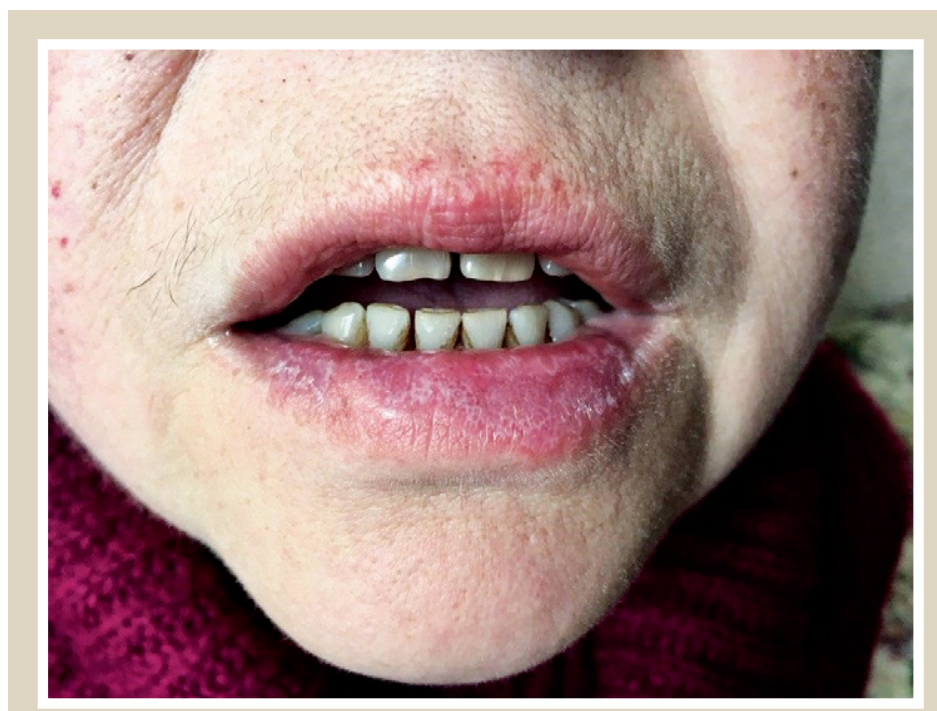

Fig. 1. Verrucous leukoplakia of the lower lip on examination (23.09.2019).

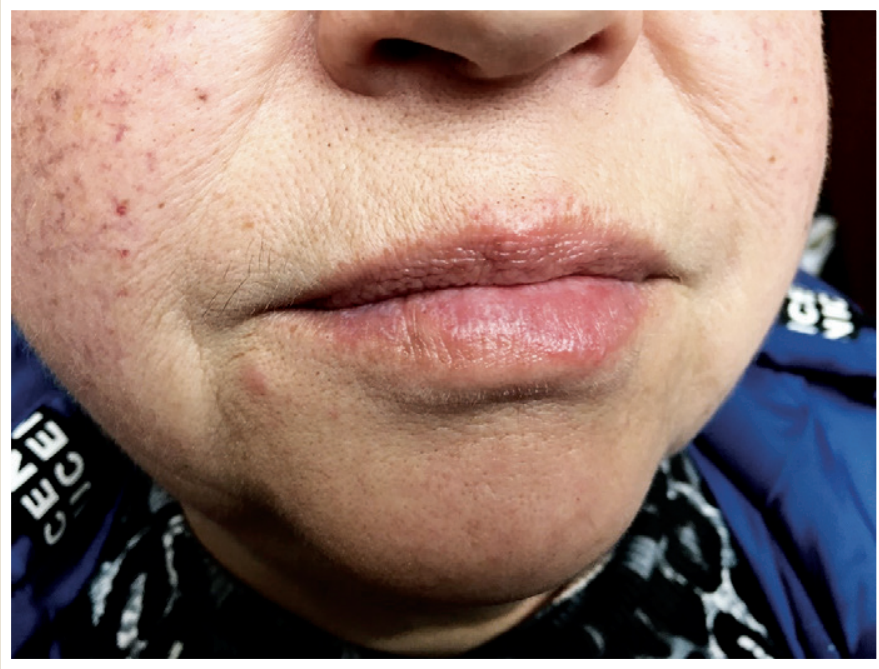

Fig. 2. Verrucous leukoplakia of the lower lip after prescribed treatment (24.10.2019).

in a form of rough skin (according to the patient's words) of 4-5 $\mathrm{mm}$ in diameter accompanied by burning and itching. The patient associated the rash occurrence with HEETS sticks and IQOS heated tobacco product as this zone was in a contact with the stick. Then the patient started to put the stick away from the affected left corner of the mouth to the right one, where the same rash appeared in several weeks. Within 3-4 weeks, the pathological process started to spread almost over the whole red border (lower lip). During further 3-4 months, the affected area started to be hardened.

During that time, the patient did not ask for professional medical aid and was not self-medicated. On examination, a milky-colored irregularly shaped plaque, 1-2 mm rising above the unchanged surface was found on the lower lip. The plaque was indurated with definite ruffled borders, clear limits, and rough surface (Fig. 1).

In order to verify the diagnosis, the following diagnostic methods were used. All the indicators of clinical blood and urine analyses, biochemical blood analysis were within normal physiological range. The culture from 
the affected area scraping revealed no fungal elements. Serologic tests for lupus erythematosus detected neither anti-double-stranded DNA (anti-dsDNA) antibodies nor antinuclear antibodies (ANA). Dermatoscopy revealed no manifestations of cutaneous squamous cell carcinoma. Oncopathology was ruled out after the patient consultation with an oncologist.

As the patient flatly refused the biopsy with further histological examination as well as the surgical treatment, the following diagnosis was made: verrucous leukoplakia of the red border (lower lip), plaque type. Considering the possible traumatization, a risk of the mentioned neoplasm degeneration, the patient was prescribed topical therapy with combined drug containing glucocorticosteroid, antibacterial and antimycotic components and received a treatment regimen for a duration of one month as follows: 2 times daily within 7 days, further three weeks - 1 time per day (at bedtime).

Due to the fact that proposed therapy improved the patient's subjective state, reduced the affected area and its infiltration, the topical cream with $1 \%$ pimecrolimus was prescribed to the affected area 2 times daily for 3 months with the purpose of the topical glucocorticosteroid drug discontinuation under continuing follow-up. The effected area practically did not disturb the woman and became more flat (Fig. 2). Dermatoscopic manifestations of oncopathology formation were absent. Since the patient kept her smoking and refused other methods of therapy, the clinical improvement was mitigated. The prescribed therapy with the use of $1 \%$ pimecrolimus cream was planned to continue as well as further long-term clinical and dermatoscopic follow-up to examine the skin state.

\section{Discussion}

In case with the present patient, the epithelial skin cancer can be the most threatening diagnosis. Oral mucous membrane diseases are suspected of being precancerous as the tissue structural changes progress to squamous cell carcinoma over the years. One of the most common facultative precancerous diseases with a high rate of malignant transformation is leukoplakia [12]. Almost in $50 \%$ of patients, leukoplakia progresses to oral cancer. The worldwide prevalence of leukoplakia is approximately $2 \%$ among all oral mucous membrane and it occurs in $13 \%$ of the red border diseases [13].

Leukoplakia is defined as an epithelial disease with hyperkeratosis of the oral mucous membrane and the red border accompanied by inflammation of the adjacent connective tissue and edema. The disease is a chronic gradually progressive condition, which develops under influence of endogenous and exogenous factors [14]. Among factors promoting the occurrence and development of leukoplakia, the following can be determined: chronic mechanical injury of the oral mucous membrane (dental prosthesis, tooth cusp etc.), unhealthy habits (smoking, alcohol abuse, putting small thing into the mouth - pencil, pen, nails etc.), contact with chemical substances (phenol, formaldehyde, iodine, bromine, gums, alkali), chronic stress, combined vitamin (vitamin A) and microelement deficiency, sexually transmitted diseases (syphilis), candidosis, HIV infection, ultraviolet radiation, chronic diseases of the gastrointestinal tract, neurodystrophic changes of mucous membranes, anemia, endocrine disorders (diabetes mellitus) etc. [15].
Regarding the presented clinical case, it should be specially emphasized that smokeless tobacco is considered as the reason of leukoplakia development in $8.4 \%$ of cases [16], but the literature does not cover the description of clinical manifestations in oral mucous membrane diseases related to IQOS heated tobacco product and HEETS sticks.

Anatomical and topographic factors increasing the risk of malignant transformation of leukoplakia are the followings: size more than $200 \mathrm{~mm}$, non-uniform texture, location on the tongue and/or the bottom of the oral cavity, CandidaAlbicans colonization or epithelial dysplasia, female sex, age more than 50 years, idiopathic leukoplakia, long existing leukoplakia $[17,18]$. Some of the listed factors were observed in our patient (sex, age) indicating the need for immediate prescription of therapy. The clinical forms of leukoplakia are the followings: simple (flat), verrucous (plaque and warty), erosive and ulcerous, hairy, candidal, soft (white sponge Pashkov nevus), Tappeiner leukoplakia [19]. The important clinical issue is the differential diagnostics between leukoplakia and hyperkeratotic form of lichen acuminatus, Bowen's disease, hyperplastic candidosis of the oral mucous membrane [19].

In order to improve diagnostic measures in addition to visual assessment of the affected area, the dermatoscopy, optical coherence tomography [20], pathomorphological examination giving an opportunity to choose both reasonable and individual treatment regimen, can be used as additional diagnostic methods.

Although leukoplakia does not have specific histological pattern and its diagnosis is based on visual examination, the biopsy is the gold standard for determination of epithelial dysplasia and malignant transformation of the affected areas providing a treatment strategy choice $[13,16]$. Histological examination reveals the following signs in specimens: hyperkeratosis, parakeratosis or acanthosis with or without epithelial dysplasia; thinning of basement membrane; presence of inflammatory area, edema and cellular infiltration in the derma $[17,19]$.

In this case, based on the clinical examination and dermatoscopy, patient's flat refusal to perform the biopsy, the diagnosis of verrucous leukoplakia, plaque type was made.

The treatment strategy choice depends on the results of diagnostics and assessment of the general patient's condition, presence of comorbid pathology. Thus, the first line of a complex therapy is the correction of provoking factors (oral cavity sanation, smoking cessation, eliminating the influence of toxic and chemical substances, selection of dental prosthesis according to shape, rational and correct dental care). It is recommended to prescribe vitamins $A$ and $E$ in form of applications and systemic use, correction of comorbid pathology, topical and systemic anti-inflammatory therapy, and sedative therapy [19].

If leukoplakia transforms into verrucous or erosive-ulcerous type, the first line therapy should be added with surgical treatment in form of complete excision within limits of normal tissues, electro- or cryodestruction with obligatory pathohistological examination. $\mathrm{CO}_{2}$-laser ablation is also used. However, a large area of the affected zone, postoperative pain, edema and large scars often may be reasons for not choosing these methods of treatment. It 
was also the case for the patient's refusal of any surgical procedures (biopsy, surgical removal) and incentive to seek therapeutic methods.

Today, topical and photodynamic therapy with photosensibilizing agents (5-aminolevulinic acid, fotolon) are also the perspective trends owing to the minimum risk of complications, side reactions, absence of recurrence and lower treatment costs [21]. Laser, i.e. coherent light, is effectively used as radiation source. For such purposes, semiconducting laser (for example, diode laser with wave length of 600-950 nm, argon laser - 448.0-514.5 nm) or solid-state laser (Nd/YAG-lasers $1064 \mathrm{~nm}, 532 \mathrm{~nm}$, $355 \mathrm{~nm}$ or $266 \mathrm{~nm}$ ) are used. As less expensive alternative, the powerful LEDs (wave length of 350-1100 nm) are also available which are portable and relatively cheap [22,23]. In our case, there was a lack of both physical and economic ability to use the beam therapy.

Despite the complexity of diagnosing leukoplakia of the oral mucous membrane and the red border, its timely detection and pathomorphological verification are the basis for rational and reasonable choice of the treatment strategy. For our patient, based on refusing to undergo surgical diagnostic and treatment methods, the chosen regimen of topical corticosteroids and calcineurin inhibitor application was beneficial in stabilization of the affected skin area, demonstrating the positive treatment results.

\section{Conclusions}

1. The literature review indicates that IQOS heated tobacco product and HEETS sticks are not less harmful in comparison with traditional tobacco products. The toxic substances content in aerosol can cause such signs of oxidative stress and endothelial dysfunction as inflammation, infections, fibrosis, and development of oncological pathology.

2. Use of IQOS heated tobacco product and HEETS sticks can be one of the provoking factors for occurrence of leukoplakia of the oral mucous membrane and the red border.

3. The use of topical glucocorticosteroids combined with topical calcineurin inhibitors can be proposed as an alternative to surgical methods of leukoplakia treatment and requires more detailed study.

Conflicts of interests: authors have no conflict of interest to declare. Конфлікт інтересів: віАсутній.

Надійшла Ао редакції / Received: 30.06.2020

Після Аоопрацювання / Revised: 06.07.2020

Прийнято Ао Аруку / Accepted: 14.07.2020

Information about authors:

Makurina H. I., MD, PhD, DSc, Associate Professor, Head of the Department of Dermatovenereology and Cosmetology with the Course of Aesthetic Medicine of Postgraduate Education Faculty, Zaporizhzhia State Medical University, Ukraine. ORCID ID: 0000-0002-5865-1901

Makarchuk O. I., MD, PhD, DSc, Associate Professor of the Department of Dermatovenereology and Cosmetology with the Course of Aesthetic Medicine of Postgraduate Education Faculty, Zaporizhzhia State Medical University, Ukraine. ORCID ID: 0000-0002-4031-2207
Dmytrenko I. P., MD, PhD, Associate Professor of the Department of Dermatovenereology and Cosmetology with the Course of Aesthetic Medicine of Postgraduate Education Faculty, Zaporizhzhia State Medical University, Ukraine.

ORCID ID: 0000-0002-3293-2748

Holovkin A. V., MD, PhD, Associate Professor of the Department of Dermatovenereology and Cosmetology with the Course of Aesthetic Medicine of Postgraduate Education Faculty, Zaporizhzhia State Medical University, Ukraine.

ORCID ID: 0000-0002-7873-6910

Sokolovska I. A., MD, PhD, Associate Professor of the Department of General Hygiene and Ecology, Zaporizhzhia State Medical University, Ukraine.

ORCID ID: 0000-0002-5664-2382

Chornenka A. S., MD, Resident of the Department

of Dermatovenereology and Cosmetology with the Course of Aesthetic Medicine of Postgraduate Education Faculty, Zaporizhzhia State Medical University, Ukraine.

ORCID ID: 0000-0003-0248-9789

\section{Відомості про авторів:}

Макуріна Г. І., А-р мед. наук, Аоцент,

зав. каф. Аерматовенерології та косметології з курсом Аерматовенерології і естетичної медицини ФПО, Запорізький Аержавний медичний університет, Україна.

Макарчук 0. І., А-р меА. наук, Аоцент каф. Аерматовенерології та косметології з курсом дерматовенерології і естетичної медицини ФПО, Запорізький державний меАичний університет, Україна.

Амитренко І. П., канА. меА. наук, Аоцент

каф. Аерматовенерології та косметології з курсом Аерматовенерології і естетичної медицини ФПО, Запорізький Аержавний медичний університет, Україна.

Головкін А. В., канА. меА. наук, Аоцент каф. Аерматовенерології та косметології з курсом дерматовенерології і естетичної медицини ФПО, Запорізький державний медичний університет, Україна.

Соколовська І. А., канА. меА. наук, Аоцент каф. загальної гігієни та екології, Запорізький державний меАичний університет, Україна.

Чорненька А. С., мікар-інтерн каф. Аерматовенерології та косметології з курсом дерматовенерології і естетичної медицини ФПО, Запорізький Аержавний медичний університет, Україна.

\section{Сведения об авторах:}

Макурина Г. И., А-р меА. наук, Аоцент, зав. каф. Аерматовенерологии и косметологии с курсом дерматовенерологии и эстетической медицины ФПО, Запорожский государственный медицинский университет, Украина.

Макарчук А. И., А-р меА. наук, Аоцент каф. Аерматовенерологии и косметологии с курсом Аерматовенерологии и эстетической меАицины ФПО, Запорожский государственный меАицинский университет, Украина.

Амитренко И. П., канА. меА. наук, Аоцент каф. Аерматовенерологии и косметологии с курсом Аерматовенерологии и эстетической медицины ФПО, Запорожский государственный медицинский университет, Украина.

Головкин А. В., канА. меА. наук, Аоцент каф. Аерматовенерологии и косметологии с курсом дерматовенерологии и эстетической медицины ФПО, Запорожский государственный меАицинский университет, Украина.

Соколовская И. А., канА. меА. наук, Аоцент каф. общей гигиены и экологии, Запорожский государственный меАицинский университет, Украина.

Чёрненькая А. С., врач-интерн каф. Аерматовенерологии и косметологии с курсом Аерматовенерологии и эстетической меАицины ФПО, Запорожский государственный меАицинский университет, Украина.

\section{References}

[1] Başaran, R., Güven, N. M., \& Eke, B. C. (2019). An Overview of iQOS ${ }^{\circledR}$ as a New Heat-Not-Burn Tobacco Product and Its Potential Effects on Human Health and the Environment. Turkish Journal of Pharmaceutical Sciences, 16(3), 371-374. https://doi.org/10.4274/ tips.galenos.2018.79095 
[2] Glantz, S. A. (2018). Heated tobacco products: the example of IQOS. Tobacco Control, 27(Suppl. 1), s1-s6. https://doi.org/10.1136/tobaccocontrol-2018-054601

[3] Cancelada, L., Sleiman, M., Tang, X., Russell, M. L., Montesinos, V. N. Litter, M. I., Gundel, L. A., \& Destaillats, H. (2019). Heated Tobacco Products: Volatile Emissions and Their Predicted Impact on Indoor Air Quality. Environmental science \& technology, 53(13), 7866-7876. https://doi.org/10.1021/acs.est.9b02544

[4] Uchiyama, S., Noguchi, M., Takagi, N., Hayashida, H., Inaba, Y., Ogura, H., \& Kunugita, N. (2018). Simple Determination of Gaseous and Particulate Compounds Generated from Heated Tobacco Products. Chemical Research in Toxicology, 31(7), 585-593. https://doi. org/10.1021/acs.chemrestox.8b00024

[5] Davis, B., Williams, M., \& Talbot, P. (2019). iQOS: evidence of pyrolysis and release of a toxicant from plastic. Tobacco Control, 28(1), 34-41. https://doi.org/10.1136/tobaccocontrol-2017-054104

[6] Leigh, N. J., Tran, P. L., O'Connor, R. J., \& Goniewicz, M. L. (2018) Cytotoxic effects of heated tobacco products (HTP) on human bronchial epithelial cells. Tobacco Control, 27(Suppl. 1), s26-s29. https://doi. org/10.1136/tobaccocontrol-2018-054317

[7] Sohal, S. S., Eapen, M. S., Naidu, V., \& Sharma, P. (2019). IQOS exposure impairs human airway cell homeostasis: direct comparison with traditional cigarette and e-cigarette. ERJ Open Research, 5(1), Article 00159-2018. https://doi.org/10.1183/23120541.00159-2018

[8] Nabavizadeh, P., Liu, J., Havel, C. M., Ibrahim, S., Derakhshandeh, R., Jacob lii, P., \& Springer, M. L. (2018). Vascular endothelial function is impaired by aerosol from a single IQOS HeatStick to the same extent as by cigarette smoke. Tobacco Control, 27(Suppl. 1), s13-s19. https:// doi.org/10.1136/tobaccocontrol-2018-054325

[9] Leigh, N. J., Palumbo, M. N., Marino, A. M., O'Connor, R. J., \& Goniewicz, M. L. (2018). Tobacco-specific nitrosamines (TSNA) in heated tobacco product IQOS. Tobacco Control, 27(Suppl. 1), s37-s38. https:// doi.org/10.1136/tobaccocontrol-2018-054318

[10] Konstantinou, E., Fotopoulou, F., Drosos, A., Dimakopoulou, N., Zagoriti, Z., Niarchos, A., Makrynioti, D., Kouretas, D., Farsalinos, K., Lagoumintzis, G., \& Poulas, K. (2018). Tobacco-specific nitrosamines: A literature review. Food and Chemical Toxicology, 118, 198-203. https:// doi.org/10.1016/i.fct.2018.05.008

[11] Brake, S. J., Barnsley, K. Lu, W. McAlinden, K. D., Eapen, M. S., \& Sohal, S. S. (2020). Smoking Upregulates Angiotensin-Converting Enzyme-2 Receptor: A Potential Adhesion Site for Novel Coronavirus SARS-CoV-2 (Covid-19). Journal of Clinical Medicine, 9(3), Article 841. https://doi.org/10.3390/jcm9030841

[12] Maia, H. C., Pinto, N. A., Pereira, J., de Medeiros, A. M., da Silveira, É. J., \& Miguel, M. C. (2016). Potentially malignant oral lesions: clinicopathological correlations. Einstein, 14(1), 35-40. https://doi. org/10.1590/S1679-45082016AO3578

[13] Borysenko, A., \& Kolenko, J. (2017). Sovremennyi podkhod k diagnostike leikoplakii slizistoi obolochki polosti rta [Modern approaches to diagnostics of oral leukoplakia]. Science yesterday, today, tomorrow: Proceedings of the XLIV International scientific-practical conference. (Issue 3, pp. 26-34). Izd. ANS «SibAK». [in Russian].

[14] Syomkin, V. A., Rabinovich, O. F., Babichenko, I. I., \& Bezrukov, A. A. (2017). Leikoplakiya: klinicheskii i patomorfologicheskii diagnoz [Leukoplakia: clinical and pathological diagnosis]. Stomatologiya, (1), 72-76. https://doi.org/10.17116/stomat201796172-76 [in Russian].

[15] Kolenko, Yu. (2016). Rol chynnykiv ryzyku v rozvytku peredrakovykh zakhvoriuvan slyzovoi obolonky porozhnyny rota [Role of risk faktors for development of prcancerous diseases of the oral mucosa]. Sovremennaya stomatologiya, (1), 53-56. [in Ukrainian]

[16] Irani, S. (2016). Pre-Cancerous Lesions in the Oral and Maxillofacial Region: A Literature Review with Special Focus on Etiopathogenesis. Iranian Journal of Pathology, 11(4), 303-322.

[17] Mohammed, F., \& Fairozekhan, A. T. (2020). Oral Leukoplakia. StatPearls [Internet]. StatPearls Publishing.

[18] Speight, P. M., Khurram, S. A., \& Kujan, O. (2018). Oral potentially malignant disorders: risk of progression to malignancy. Oral Surgery, Oral Medicine, Oral Pathology and Oral Radiology, 125(6), 612-627. https://doi.org/10.1016/j.0000.2017.12.011

[19] Kostina, I. N., Epishova, A. A., Grigor'ev, S. S., Chernysheva, N. D., \& Sorokoumova, D. V. (2019). Predrakovye zabolevaniya slizistoi obolochki polosti rta, krasnoi kaimy gub i kozhi litsa [Pre-cancer diseases of the mucous membrane of the oral cavity, red border of the lips and facial skin]. Izdatel'skii Dom «TIRAZh». [in Russian].

[20] Syomkin, V. A., Rabinovich, O. F., Agapitova, L. P., Bezrukov, A. A. \& Babichenko, I. I. (2018). Diagnosticheskaya tsennost' metoda kogerentnoi tomografii u bol'nykh s leikoplakiei slizistoi obolochki rta [Diagnostic value of optical coherence tomography for oral leukoplakia assessment]. Stomatologiya, (1), 37-39. https://doi.org/10.17116/ stomat201897137-39 [in Russian].

[21] Istomin, Yu. P., Artemyeva, T. P. \& Tzerkovsky, D. A. (2016). Fotodinamicheskaya terapiya leikoplakii slizistoi obolochki polosti rta $\mathrm{s}$ fotosensibilizatorom fotolon [Photodynamic therapy with photosensitizer photolon for oral leukoplakia]. Biomedical Photonics, 5(2), 13-20. https:// doi.org/10.24931/2413-9432-2016-5-2-13-20 [in Russian].

[22] Chen, Q., Dan, H., Tang, F., Wang, J., Li, X., Cheng, J., Zhao, H., \& Zeng, X. (2019). Photodynamic therapy guidelines for the management of oral leucoplakia. International Journal of Oral Science, 11(2), Article 14. https://doi.org/10.1038/s41368-019-0047-0

[23] Bogomolov, A. Ye. (2018). Characteristic of nicotine delivery devices - electronic cigarettes - as a tool to fight against tobacco dependence. Zaporozhye medical journal, 20(2), 275-279. https://doi. org/10.14739/2310-1210.2018.2.125528 